\title{
Faktor Pendorong Penggunaan Derivatif: Studi dari Indonesia
}

\author{
Ana Fitria \\ Fakultas Ekonomi dan Bisnis Islam UIN Ar-Raniry \\ e-mail: anafitria.aceh@gmail.com
}

\begin{abstract}
Abstrak
Tujuan dari penelitian ini adalah untuk menguji pengaruh ukuran perusahaan, leverage, likuiditas, ukuran dewan, dewan komisaris independen, dan komite audit mengenai penggunaan derivatif pada perusahaan sektor logam dan turunannya yang terdaftar di Bursa Efek Indonesia (BEI) untuk tahun 2012 -2014. Penelitian kuantitatif ini menggunakan metode purposive sampling dan menggunakan pendekatan deduktif. Ada 39 perusahaan yang diamati yang masing-masing menghasilkan laporan tahunan dan laporan keuangan yang telah diaudit dari tahun 2012 sampai 2014. Model analisis regresi logistik ordinal digunakan untuk menguji hipotesis, dan data diolah menggunakan bantuan program SPSS Versi 19. Hasil penelitian menunjukkan bahwa hanya ukuran perusahaan, leverage dan komite audit yang berpengaruh signifikan terhadap penggunaan derivatif pada tingkat signifikansi yang berbeda. Tiga variabel independen lainnya tidak berpengaruh signifikan terhadap determinan penggunaan derivatif.
\end{abstract}

Kata kunci: Derivatif, manajemen resiko, ukuran perusahaan, leverage, likuiditas, corporate governance.

\section{PENDAHULUAN}

Globalisasi telah mengubah cara perusahaan melakukan bisnis; dari pasar tradisional ke pasar global yang bebas. Hal tersebut pada akhirnya memaksa perusahaan untuk mengembangkan strategi kreatif untuk bertahan hidup. Sebelumnya, perusahaan hanya harus memikirkan pesaing lokal sementara saat ini banyak unsur lainnya yang harus dipertimbangkan karena keterbukaan pasar internasional yang berubah dengan cepat, termasuk mata uang dan suku bunga sebagai bagian dari risiko finansial.

Risiko hukum dan fisik seperti bencana alam dan/atau tuntutan hukum dapat ditangani oleh manajemen risiko tradisional, sementara manajemen risiko keuangan berfokus pada risiko yang lebih luas yang sangat mudah dikelola dengan instrumen keuangan.

Ada beberapa cara untuk mengelola risiko keuangan di pasar global. Misalnya, risiko nilai tukar dikelola dengan lindung nilai alami, pengelolaan kas dan penyesuaian transaksi antar perusahaan, lindung nilai pendanaan internasional dan hedging mata uang melalui derivatif (Van Horne \& Wachowicz, 2005). Derivatif menjadi instrumen lindung nilai karena karakteristik kontrak yang melibatkan dua pihak dalam membeli dan menjual barang termasuk komoditas dan saham pada tanggal tertentu di masa depan dengan harga yang disepakati saat ini. Perusahaan publik yang banyak menangani risiko semacam ini harus memastikan bahwa pengendalian risiko berjalan dengan baik. Sebagai pemenuhan kebutuhan ini, lembaga keuangan telah memperkenalkan derivatif sebagai instrumen kontrak keuangan untuk melakukan lindung nilai atas nilai investasi. Menurut Bellalah (2010), derivatif mengacu pada alat keuangan yang secara tidak langsung dijual di pasar primer dan digunakan untuk mengelola risiko dari transaksi tertentu. Ada empat jenis derivatif yang berbeda, yaitu forward, kontrak futures, swap, dan opsi. Masing-masing memiliki karakteristik yang berbeda. 
Beberapa negara di Asia memiliki banyak pasar potensial untuk dikembangkan namun mengandung risiko finansial yang lebih besar daripada negara-negara di Eropa. Indonesia sebagai negara berkembang di Asia Tenggara adalah contoh yang cocok untuk kondisi tersebut. Suku bunga dan nilai tukar masih tidak stabil dan mudah terpengaruh oleh beberapa isu dari kegiatan ekonomi hingga faktor politik. Perusahaan harus memperhitungkan kondisi ini sebagai faktor eksternal untuk lindung nilai investasinya karena nilai uang dapat berubah sewaktuwaktu.

Menurut Bank Dunia (2010), pasar Indonesia telah menjanjikan pertumbuhan yang masih sangat fluktuatif dalam aspek keuangan dari arus masuk modal dan arus keluar, nilai tukar, hingga harga komoditas. Berdasarkan fakta ini, derivatif merupakan kebutuhan yang semakin meningkat sebagai alat lindung nilai untuk mencegah risiko keuangan. Apalagi, dari tahun 2011 sampai 2015, nilai Rupiah Indonesia (IDR) terdepresiasi 56\% terhadap Dolar Amerika Serikat (USD), yaitu dari Rp 9.000 per USD menjadi Rp 14.000 per USD (Bloomberg, 2015).

Ilustrasi lain adalah tentang harga minyak. Minyak merupakan salah satu komoditas penting yang dibutuhkan oleh perusahaan multinasional untuk menjalankan bisnis. Dalam kasus perusahaan percaya bahwa akan terjadi kenaikan harga minyak di masa depan, perusahaan akan mengatur kontrak berjangka sebagai bagian dari derivatif untuk melakukan lindung nilai terhadap risiko kenaikan harga.

Selanjutnya, pertimbangan internal di dalam perusahaan dapat mempengaruhi keputusan penggunaan derivatif. Ukuran perusahaan berhubungan positif dengan penggunaan derivative, namun tidak dengan likuiditas (Lantara, 2012). Selain itu, perusahaan lebih relatif memilih untuk menggunakan derivatif jika menghasilkan nilai yang besar dan perusahaan memiliki lebih banyak hutang daripada ekuitas dalam struktur modalnya (Nguyen \& Faff, 2003). Sementara itu, penelitian Triki (2005) menunjukkan bahwa hutang berpengaruh negatif terhadap aktivitas lindung nilai. Penentu lain penggunaan derivatif yang banyak dipelajari oleh peneliti akhir-akhir ini adalah corporate governance. Praktik tata kelola perusahaan yang baik telah mempengaruhi berbagai jenis keputusan manajerial termasuk mengelola risiko keuangan. Menurut Sekretaris Jenderal Organisasi Kerjasama Ekonomi dan Pembangunan (2015), tata kelola perusahaan mencakup sekelompok hubungan antara orang-orang yang terkait dengan perusahaan termasuk manajemen, dewan direksi, pemegang saham dan pemangku kepentingan lainnya dalam menjalankan tujuan bisnis tertentu yang sebelumnya telah ditetapkan. Penggunaan derivatif memiliki hubungan positif dengan jumlah direktur eksekutif sedangkan berhubungan negatif dengan ukuran dewan (Osuoha et al., 2015). Studi lain mengenai tata kelola perusahaan menunjukkan bahwa kebijakan manajemen risiko dipengaruhi oleh pendidikan direksi di bidang keuangan, tingkat pendidikan anggota dewan juga mempengaruhi keputusan lindung nilai namun tidak di komite audit (Dionne \& Triki, 2005). Penelitian ini lebih difokuskan pada faktor internal penggunaan derivatif dan mencoba menganalisa faktor-faktor yang mempengaruhi keputusan perusahaan.

Pembangunan perekonomian dalam suatu wilayah dihadapkan pada dua trend mainstream kebijakan perekonomian, yaitu kebijakan untuk mengejar pertumbuhan ekonomi, dan kebijakan untuk mengutamakan pemerataan pembangunan. Kebijakan bersifat mendorong pertumbuhan ekonomi pada satu wilayah tertentu biasanya akan dihadapkan oleh munculnya disparitas (kesenjangan) antar wilayah. Disparitas dalam pembangunan antar wilayah disebabkan oleh adanya perbedaan endowments atau sumber daya masing-masing wilayah, sehingga daerah menjadi terklasifikasikan dengan isitilahistilah seperti daerah maju, daerah sedang berkembang, dan daerah terbelakang.

Unsur besar lain dalam berbisnis adalah tingkat bunga. Sebuah perusahaan cenderung meminjam uang dari bank sebagai salah satu 
sumber pendanaannya. Akibatnya, perusahaan harus membayar hutang ditambah tingkat bunga. Di Indonesia, suku bunga dasar ditetapkan oleh Bank Indonesia (BI). Tingkat suku bunga berfluktuasi sebagai akibat kebijakan moneter pemerintah Indonesia. Perusahaan yang meminjam uang dari bank juga harus mendapat dampak dari kebijakan ini. Misalnya, perusahaan meminjam uang pada 11 Desember 2012 di BI-rate 5,75\% dalam lima tahun kontrak. Situasi lapangan menunjukkan bahwa tingkat kenaikannya meningkat selama bertahun-tahun. Jika perusahaan memasukkan kontrak derivatif sehingga suku bunga tetap di level 5,75\%, maka perusahaan akan berhasil melakukan penghematan yang besar.

Prevost et al. (2000) serta Berkman dan Bradbury (1996) merangkum bahwa usaha dengan skala besar berkemungkinan besar akan menggunakan derivatif daripada perusahaan yang lebih kecil. Metode penalaran prinsipnya adalah adanya skala ekonomis untuk penggunaan derivatif. Biaya untuk menggunakan derivatif bisa dipandang sebagai biaya variabel, dan biasanya hanya perusahaan besar yang memiliki uang lebih banyak untuk menanggung biaya tersebut. Sejalan dengan penelitian tersebut, semakin besar ukuran perusahaan maka semakin besar kemungkinannya menggunakan derivatif. Sebuah perusahaan yang menggunakan derivatif kemungkinan besar merupakan perusahaan skala besar (Nance et al., 1993).

Penggunaan derivatif tidak lepas dari kebutuhan dana yang cepat dan tersedia, sehingga likuiditas sangat mungkin berkaitan dengan derivatif. Carter dan Sinkey (1998) berpendapat bahwa masalah likuiditas terkait dengan persyaratan derivatif sebagai instrumen pendukung. Mereka berpendapat bahwa semakin rendah likuiditas perusahaan, semakin tinggi probabilitas penggunaan derivatif. Froot et al. (1993) mencatat bahwa ketika sebuah perusahaan tidak bisa mencoba semua peluang investasi yang disebabkan keharusan likuiditas yang cepat, perusahaan itu mungkin akan menggunakan derivatif untuk memoderasi masalah ini. Hal yang sama juga ditemukan oleh Berkman dan Bradbury (1996) serta Nguyen dan Faff (2002), yang membuktikan bahwa likuiditas secara kontras mendorong penggunaan derivatif pada sebuah perusahaan. Oleh karena itu, dapat dikatakan bahwa semakin likuid perusahaan, maka semakin tinggi sumber moneternya sehingga tidak perlu menggunakan derivatif.

Leverage menjadi salah satu variabel yang mempengaruhi keputusan untuk menggunakan derivatif karena merupakan bagian dari financial distress. Berdasarkan literatur manajemen risiko, perusahaan yang memiliki tingkat leverage tinggi memiliki kecenderungan yang lebih besar untuk menggunakan derivatif karena hal tersebut akan mengurangi risiko kebangkrutan (Warner, 1977; Geczy et al., 1997; Guay \& Kothari, 2003).

Board size memiliki pengaruh yang signifikan pada penggunaan derivatif (Borokhovich et al., 2004). Semakin besar ukuran board size, semakin banyak derivatif yang digunakan dalam aktivitas lindung nilai. Beberapa literatur sebelumnya mengenai pengaruh dewan komisaris independen terhadap derivatif menunjukkan hasil yang berbeda. Studi Borokhovich et al. (2004) menemukan bahwa penggunaan derivatif lebih tinggi jika jumlah dewan komisaris independen lebih banyak dari direktur internal. Sementara Dionne dan Triki (2013) menunjukkan bukti yang menyatakan bahwa tidak ada korelasi antara dewan komisaris independen dan aktivitas lindung nilai. Penelitian Osuoha et al. (2015) menyebutkan bahwa banyak perusahaan Afrika cenderung menggunakan derivatif jika memiliki tata kelola perusahaan yang kuat, terutama pengawasan yang kuat dari komite audit.

Berdasarkan hasil telaah atas beberapa penelitian sebelumnya, penelitian ini akan membahas faktor pendorong penggunaan derivatif di Indonesia dengan kerangka pikir seperti terlihat dalam Gambar 1. 


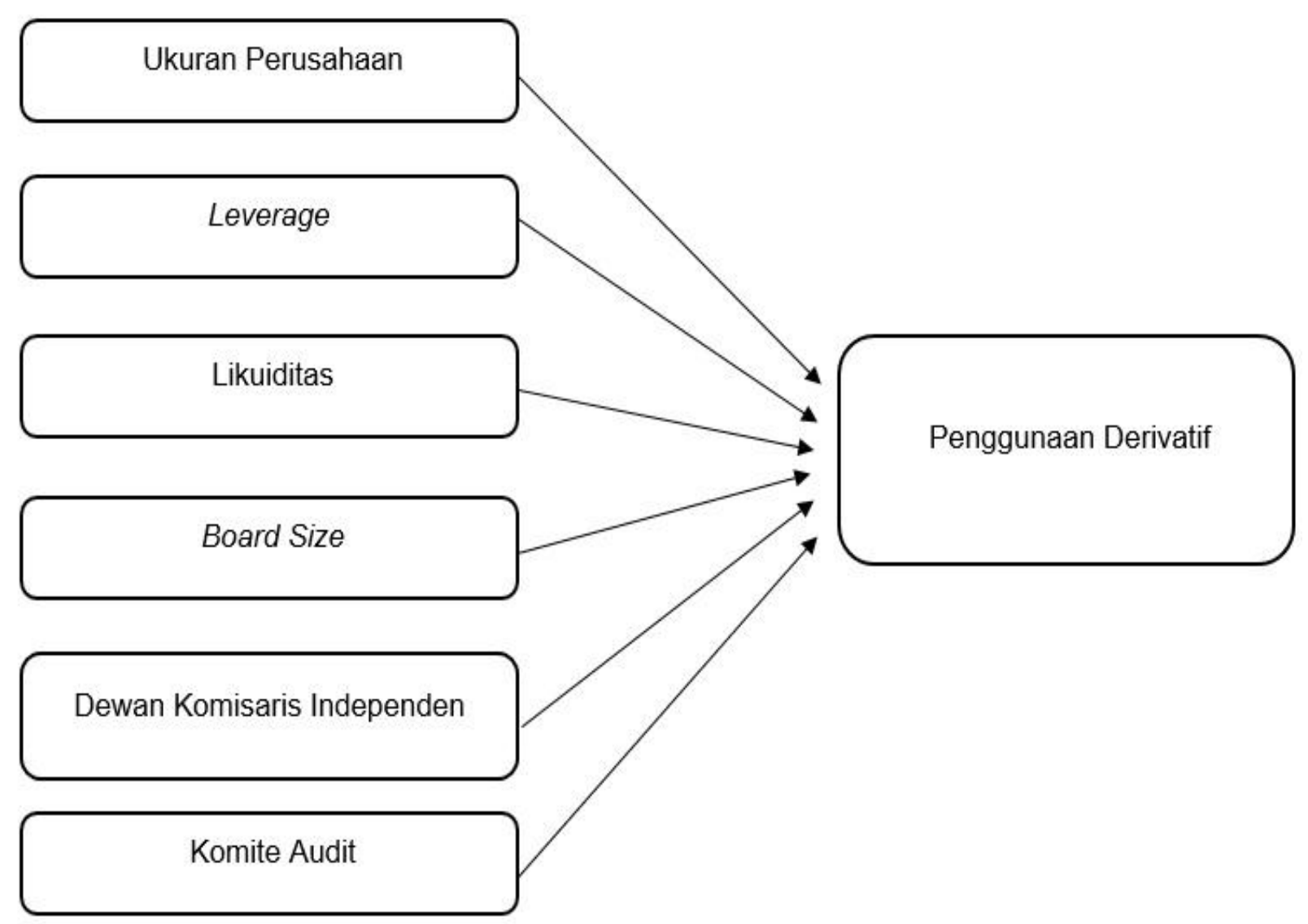

Sumber: Diolah Peneliti, Tahun 2015.

\section{Gambar 1. Kerangka Pikir Penelitian}

\section{METODE PENELITIAN}

Penelitian ini menganalisis faktor-faktor penentu penggunaan derivatif oleh suatu perusahaan. Penelitian ini didasarkan pada teori manajemen risiko yang digunakan untuk melindungi perusahaan dari kerugian; lindung nilai merupakan salah satu caranya. Pada prinsipnya, aktivitas lindung nilai adalah untuk melindungi aset dari perubahan harga di masa depan adalah dengan menggunakan instrumen derivatif. Penelitian ini memiliki dua variabel utama. Derivatif merupakan variabel dependen; sementara variabel independen adalah ukuran perusahaan, leverage, likuiditas, board size, dewan komisaris independen, dan komite audit. Uraian masing-masing variabel itu adalah sebagai berikut.

a. Derivatif.

Derivatif dibagi menjadi empat jenis, yaitu opsi, forward, future, dan kontrak swap. Berdasarkan informasi yang diberikan dalam laporan tahunan perusahaan, definisi operasional derivatif dalam penelitian ini adalah:

- Jika sebuah perusahaan menggunakan satu derivatif, maka diberi angka 1;

- Jika sebuah perusahaan menggunakan dua derivatif, maka diberi angka 2;

- Jika sebuah perusahaan menggunakan tiga derivatif, maka diberi angka 3 ;

- Jika sebuah perusahaan menggunakan empat derivatif, maka diberi angka 4; dan,

- Jika sebuah perusahaan tidak menggunakan derivatif, maka diberi angka 0 .

b. Ukuran Perusahaan.

Perusahaan memiliki cara yang berbeda dalam pengambilan keputusan. Salah satu faktor yang menciptakan perbedaan adalah ukuran perusahaan. Perusahaan dengan ukuran besar lebih 
mudah mendapatkan sumber dana baik secara eksternal maupun internal (Short \& Keasy, 1999). Semakin besar sebuah perusahaan, semakin besar risikonya. Ukuran perusahaan direpresentasikan:

\section{Ukuran perusahaan $=$ Total aset}

\section{c. Leverage.}

Leverage mencerminkan kemampuan perusahaan untuk membayar kembali hutang menggunakan ekuitasnya sendiri. Debt Equity Ratio (DER) adalah alat untuk mengukur leverage suatu perusahaan. DER adalah perbandingan antara hutang dan ekuitas di perusahaan. Secara teknis, DER dirumuskan (Ang, 1997):

$$
D E R=\frac{\text { Total Kewajiban }}{\text { Total Ekuitas }}
$$

d. Likuiditas.

Likuiditas berhubungan dengan kemampuan perusahaan untuk membayar kewajiban jangka pendeknya. Tingkat likuiditas perusahaan dapat diukur dengan rasio likuiditas. Dalam penelitian ini, rasio lancar digunakan untuk mengukur tingkat likuiditas.

$$
C R=\frac{\text { Aktiva Lancar }}{\text { Kewajiban Lancar }}
$$

\section{e. Board Size.}

Board size yang digunakan dalam penelitian ini adalah jumlah anggota dewan direksi di perusahaan yang disebutkan dalam laporan tahunannya.

\section{Board Size $=$ Jml anggota dewan direksi}

f. Dewan Komisaris Independen.

Dewan komisaris independen didefinisikan sebagai direksi independen yang tidak berafiliasi dengan manajemen di perusahaan. Proporsi dewan komisaris independen diukur dengan persentase anggota Komisaris yang berasal dari luar perusahaan dibagi seluruh anggota komisaris perusahaan.

$\%$ Dewan Komisaris Independen = (Jumlah komisaris independen) / (Jumlah komisaris) g. Komite Audit.

Komite audit dibentuk oleh dewan komisaris sesuai dengan pedoman tata kelola perusahaan (Setyapurnama \& Norpratiwi, 2007). Dalam penelitian ini, komite audit didefinisikan sebagai jumlah anggota komite audit di perusahaan.

\section{Komite Audit $=$ Jumlah anggota komite audit}

Perusahaan manufaktur yang fokus pada produk logam dan sekutu yang terdaftar di Bursa Efek Indonesia (BEI) pada periode antara 2012 dan 2014 adalah populasi penelitian ini. Pertimbangan memilih perusahaan adalah karena perusahaan tersebut bukan bergerak di jasa finansial. Perusahaan finansial cenderung menggunakan derivatif tidak hanya untuk tujuan lindung nilai tetapi juga untuk tujuan spekulasi. Untuk meminimalisasi bias dari tujuan penelitian ini yaitu ingin mengetahui faktor-faktor penentu penggunaan derivatif sebagai alat lindung nilai, maka perusahaan non keuangan ditentukan sebagai populasi.

Populasi yang digunakan dalam penelitian ini adalah kelompok perusahaan yang terdaftar di Bursa Efek Indonesia (BEI) mulai 2012 hingga 2014 yang memfokuskan bisnisnya di bidang industri logam dan industri sekutu. Awalnya, ada 16 perusahaan yang terdaftar di industri ini setiap tahunnya. Namun, setelah mengumpulkan semua laporan tahunan dan laporan keuangan, hanya ada 13 perusahaan yang tersisa. Alasan untuk menarik keluar tiga perusahaan adalah laporan tahunan tidak tersedia untuk umum atau laporan keuangan tidak dapat dinilai. Proses pull-out disajikan pada Tabel 1.

Ketiga belas perusahaan tersebut dikalikan dengan 3 tahun sehingga sampelnya adalah 39 perusahaan. Laporan tahunan dan laporan keuangan perusahaan ini dari tahun 2012 sampai 2014 diperiksa untuk mencari data variabel dependen dan independen.

Data yang terkumpul akan dianalisis terlebih dahulu dengan statistik deskriptif sebelum analisis lain untuk mengetahui keseluruhan gambaran deskriptif data berdasarkan nilai mean, standar deviasi, dan minimum dan maksimal. 
Tabel 1. Daftar Perusahaan

\begin{tabular}{lcc}
\hline \multirow{2}{*}{$\begin{array}{c}\text { Perusahaan Terdaftar di } \\
\text { Industri Logam dan Sejenisnya }\end{array}$} & \multicolumn{2}{c}{ Ketersediaan Informasi } \\
\cline { 2 - 3 } Alakasa Industrindo Tbk. & Laporan Tahunan & Laporan Keuangan \\
\hline Alumindo Light Metal Industry Tbk. & Ada & Ada \\
\hline Betonjaya Manunggal Tbk. & Ada & Ada \\
\hline Citra Tubindo Tbk. & Ada & Ada \\
\hline Gunawan Dianjaya Steel Tbk. & Ada & Ada \\
\hline Indal Aluminium Industry Tbk. & Ada & Ada \\
\hline Jakarta Kyoei Steel Works Tbk. & Tidak Ada & Ada \\
\hline Jaya Pari Steel Tbk. & Ada & Ada Ada \\
\hline Krakatau Steel (Persero) Tbk. & Ada & Ada \\
\hline Lion Metal Works Tbk. & Ada & Ada \\
\hline Lionmesh Prima Tbk. & Ada & Ada \\
\hline Pelangi Indah Canindo Tbk. & Ada & Ada \\
\hline Pelat Timah Nusantara Tbk. & Ada & Ada \\
\hline Saranacentral Bajatama Tbk. & Ada & Ada \\
\hline Steel Pipe Industry of Indonesia Tbk. & Tidak Ada & Tidak Ada \\
\hline Tembaga Mulia Semanan Tbk. & Tidak Ada & Ada \\
\hline \multicolumn{1}{c}{ Total Perusahaan } & & $\mathbf{1 6}$ \\
\hline Perusahaan Tanpa Laporan Tahunan & & $\mathbf{( 1 )}$ \\
\hline Tuanan & \\
\hline
\end{tabular}

Sumber: Diolah Peneliti, Tahun 2015.

Selanjutnya model regresi logistik ordinal digunakan karena penelitian ini memiliki variabel dependen ordinal $(0,1,2,3$, dan 4). Model yang digunakan untuk regresi logistik ordinal adalah model logit. Model logit adalah model logit kumulatif dimana ada karakteristik ordinal respon $\mathrm{Y}$ seperti yang digariskan dalam kesempatan kumulatif untuk membuat model. Model logit kumulatif diperoleh dengan membandingkan peluang kumulatif bahwa peluang kurang dari atau sama dengan kategori respon $\mathrm{j}$ pada variabel $\mathrm{p}$ prediktor yang dinyatakan dalam vektor $\mathrm{X}, \mathrm{P}$ $(\mathrm{Y} \leq \mathrm{j} \mid \mathrm{X})$ dengan peluang lebih besar daripada kategori respon $\mathrm{j}, P(Y>j \mid X)$ (Hosmer \& Lemeshow, 2000).
Regresi Logistik Ordinal dalam penelitian ini akan diperiksa oleh SPSS, dengan tahapan:

a. Case processing summary.

Pada tahap ini, SPSS akan meringkas variabel dan nilainya karena perlu untuk memastikan variabel yang dianalisis adalah variabel yang benar.

b. Model Fitting information.

Tahap ini akan memberikan preview tentang kemampuan untuk memprediksi hasilnya. Perbandingan antara model 'Intercept Only' dan model 'Final' dilakukan untuk mengetahui tingkat signifikansi data. Dalam SPSS, akan ada tabel yang berisi nilai -2 log-likelihood (-2LL) dan chi-square untuk menguji 
perbedaan antara -2LL untuk kedua model. Jika signifikansi nilai statistik chi-square $p<0,0005$ maka modelnya signifikan dan akan memberi perkiraan data yang bagus.

c. Tabel Goodness-of-Fit. Statistik chikuadrat Pearson dalam tabel uji kesesuaian dimaksudkan untuk menguji konsistensi data yang diamati dengan model.

\section{$H_{0}=$ Data sesuai dengan model.}

Jika nilai $p$ besar, hipotesis nol diterima dan ini adalah model yang bagus. Jika tidak, kecocokannya tidak baik jika $p<$ 0,05; Asumsi ditolak.

d. Statistik Pseudo R-square. Ada tiga perkiraan yang dihitung dalam statistik R2 untuk model regresi logistik dan ordinal.

e. Tabel Parameter Estimasi. Tabel Parameter Estimasi menunjukkan hubungan antara setiap variabel independen dan variabel dependen. Hasil ini memberikan nilai signifikansi untuk mengetahui apakah hasilnya dipengaruhi secara signifikan oleh variabel penjelas atau tidak. Tingkat signifikansi yang diterapkan pada penelitian ini adalah $1 \%, 5 \%$, dan $10 \%$.

\section{HASIL ANALISIS}

Statistik deskriptif memberi gambaran karakteristik variabel yang diamati dalam penelitian ini. Statistik deskriptif dari variabel yang digunakan dirangkum dalam Tabel 2 .

Ferry dan Jones (dalam Sujianto, 2001) mengemukakan bahwa ukuran perusahaan digambarkan sebagai ukuran total aset yang dimiliki oleh perusahaan. Nilai terendah ukuran perusahaan adalah 129 yang dimiliki oleh Lionmesh Prima Tbk. pada 2012, yang berarti total aset yang dimiliki hanya Rp. 129 milyar. Total aset tertinggi adalah sebesar Rp. 32.324 milyar milik Krakatau Steel (Persero) Tbk. pada tahun 2014. Skor rata-rata ukuran perusahaan adalah 3.131,44 dengan standar deviasi 7,601.38, yang berarti bahwa pada umumnya, perusahaan di industri logam dan sejenisnya selama tahun 2012-2014 memiliki ukuran perusahaan rata-rata sebesar $\mathrm{Rp}$. 3.131.435.900,- Standar deviasi ukuran perusahaan dibandingkan rata-rata skornya mengatakan bahwa variasi data sangat besar.

Transaksi leverage sebagian besar dibiayai oleh hutang (Moles \& Terry, 1997). Dalam penelitian ini, leverage mengacu pada Debt to Equity Ratio (DER). Nilai minimum leverage sebesar 0,04 dimiliki oleh Jaya Pari Steel Tbk. pada 2013, sedangkan nilai maksimumnya adalah 5,15 yang dicapai oleh Indal Aluminium Industry Tbk. pada tahun 2014. Angka tersebut menunjukkan bahwa leverage berkisar antara 0,04 dan 5,15 dan tidak ada perusahaan yang diidentifikasi tidak menggunakan hutang dalam pembiayaan mereka. Rasio rata-rata DER adalah 1,63 dengan standar deviasi 1,48. Variasi data sedikit menyebar dan perusahaan masih mempertahankan rasio leverage yang baik (rata-rata masih di bawah 2,0).

Tabel 2. Statistik Deskriptif

\begin{tabular}{cccccc}
\hline & $\mathrm{N}$ & Minimum & Maximum & Mean & Std. Deviation \\
\hline Ukuran Perusahaan & 39 & 129.00 & 32324.00 & 3131.4359 & 7601.37483 \\
\hline Leverage & 39 & .04 & 5.15 & 1.6279 & 1.48605 \\
\hline Likuiditas & 39 & .75 & 464.98 & 20.5572 & 82.92588 \\
\hline Board Size & 39 & 2.00 & 7.00 & 4.2821 & 1.33670 \\
\hline $\begin{array}{c}\text { Dewan Komisaris } \\
\text { Independen }\end{array}$ & 39 & .00 & .50 & .3915 & .10135 \\
\hline Komite Audit & 39 & 2.00 & 5.00 & 3.1282 & .46901 \\
\hline Derivatif & 39 & 0 & 3 & .56 & .995 \\
\hline Valid N (listwise) & 39 & & & & \\
\hline
\end{tabular}

Sumber: Diolah Peneliti, Tahun 2015. 
Tabel 3. Case Processing Summary

\begin{tabular}{lccc}
\hline \multirow{2}{*}{ Derivatif } & & $\mathrm{N}$ & $\begin{array}{c}\text { Marginal } \\
\text { Percentage }\end{array}$ \\
& 0 & 28 & .7 \\
\cline { 2 - 4 } & 1 & 3 & .1 \\
\cline { 2 - 4 } & 2 & 5 & .1 \\
\hline Valid & 3 & 3 & .1 \\
\hline Missing & & 39 & 1.0 \\
\hline Total & & 0 & \\
\hline
\end{tabular}

Sumber: Data sekunder (diolah), Tahun 2015.

Rasio likuiditas adalah unit standar untuk menunjukkan kemampuan perusahaan untuk memenuhi hutang jangka pendeknya kepada pemberi pinjaman (Moles \& Terry, 1997). Rasio aset lancar terendah 0,75 dimiliki oleh Krakatau Steel (Persero) Tbk. Pada 2014, rasio tertinggi adalah 464,98 (Jaya Pari Steel Tbk.) di tahun yang sama. Angka ini berarti bahwa hanya $75 \%$ dari hutang jangka pendek yang dapat ditutupi oleh total aktiva lancar yang dimiliki oleh Krakatau Steel (Persero) Tbk. sementara Jaya Pari Steel Tbk. memiliki jumlah aset lancar yang berlebih untuk membayar kewajiban lancar sampai 464,98 kali. Skor rata-rata untuk variabel ini adalah 20,56 yang berarti perusahaan sampel memiliki lebih dari cukup aktiva lancar untuk menutupi kewajiban lancar dan penyebaran data sebesar 82,93 yang menciptakan variasi yang besar.

Board size digambarkan sebagai total direksi di dewan perusahaan. Setidaknya ada dua orang di dewan direksi Pelangi Indah Canindo Tbk. dari 2012 hingga 2014 dan tujuh direksi setiap tahun di Krakatau Steel (Persero) Tbk. Rata-rata jumlah dewan direksi adalah 4 dengan penyebaran data kecil $(1,34)$.

Dewan komisaris independen adalah rasio yang menafsirkan sejumlah komisaris independen di dewan dibandingkan dengan jumlah total komisaris. Pada 2014, Alakasa Industrindo Tbk. tidak memiliki komisaris independensementara beberapa perusahaan lain setiap tahun memberikan setengah porsi dewan komisaris kepada komisaris independen mereka. Skor rata-rata 0,39 yang memiliki variasi data kecil, hanya 0,10 .
Skor rata-rata orang yang duduk di komite audit perusahaan adalah 3,13 dan datanya sedikit berbeda dengan standar deviasi 0,47. Jumlah komite audit paling sedikit ada di Betonjaya Manunggal Tbk. dengan hanya dua anggota pada tahun 2012 sementara lima orang maksimal menjabat sebagai komite audit Pelat Timah Nusantara Tbk. pada tahun 2014

Di antara 39 perusahaan sampel, tidak satupun dari mereka menggunakan empat jenis derivatif. Total derivatif tertinggi yang digunakan hanya tiga jenis dan hanya di aplikasikan oleh satu perusahaan bernama Krakatau Steel (Persero) Tbk. dari tahun 2012 sampai 2014. Kebanyakan dari mereka tidak menggunakan derivatif.

\section{Regresi Logistik Ordinal}

a. Case Processing Summary.

Tabel 3 menjelaskan bahwa semua data valid dan tidak ada data yang hilang yang berarti hasilnya berasal dari data asli tanpa dimodifikasi. Hasilnya disesuaikan dengan sempurna dengan masukan dan informasi yang dihasilkan dari hasil akan menjelaskan keseluruhan fenomena yang terjadi di perusahaan sampel selama tiga tahun yang ditentukan.

b. Model Fitting Information.

Tabel 4 menunjukkan prediksi hasil. Perbandingan antara 'Intercept Only' dan 'Final' menghasilkan nilai signifikansi Chisquare secara statistik. Ini mengindikasikan bahwa prediksi model bagus. 
Tabel 4. Model Fitting Information

\begin{tabular}{lrrrr}
\hline Model & $\begin{array}{c}-2 \text { Log } \\
\text { Likelihood }\end{array}$ & $\begin{array}{c}\text { Chi- } \\
\text { Square }\end{array}$ & df & \multicolumn{1}{c}{ Sig. } \\
\hline Intercept Only & 69.877 & & & \\
\hline Final & .000 & 69.877 & 6 & .000 \\
\hline
\end{tabular}

Sumber: Diolah Peneliti, Tahun 2015.

c. Goodness-of-Fit.

Tabel 5 menginformasikan derajat konsistensi data yang diamati dengan model. Nilai $p$ adalah 1,00 yang lebih besar dari 0,05 , karenanya dapat disimpulkan bahwa datanya sangat konsisten dengan model.

Tabel 5. Goodness-of-Fit

\begin{tabular}{lrcl}
\hline & $\begin{array}{c}\text { Chi- } \\
\text { Square }\end{array}$ & df & Sig. \\
\hline Pearson & 21.450 & 108 & 1.000 \\
\hline Deviance & 15.875 & 108 & 1.000 \\
\hline $\begin{array}{l}\text { Sumber: Data } \\
\text { 2015 }\end{array}$ & sekunder & (diolah), & Tahun
\end{tabular}

\section{d. Pseudo R-Square Statistics.}

Tabel 6 menyajikan nilai $R^{2}$ pseudo. Berdasarkan nilai $80 \%$ untuk Cox dan Snell, 100\% untuk Nagelkerke, dan 100\% untuk McFadden, maka variabel independen dikatakan dapat menjelaskan variabel dependen dalam penelitian ini.

Tabel 6. Pseudo R-Square

\begin{tabular}{lr}
\hline Cox and Snell & .833 \\
\hline Nagelkerke & 1.000 \\
\hline McFadden & 1.000 \\
\hline
\end{tabular}

Sumber: Data sekunder (diolah), Tahun 2015

\section{e. Parameter Estimasi.}

Tabel 7 tentang Parameter Estimasi memberikan informasi tentang hubungan antara variabel independen dan variabel dependen. Tingkat signifikansi (sig.) menyatakan apakah variabel independen memiliki pengaruh signifikan terhadap variabel dependen atau tidak. Hasil yang diperoleh menunjukkan bahwa:
- Ukuran perusahaan memiliki pengaruh signifikan terhadap perubahan keputusan penggunaan derivative, karena nilai Sig.nya sebesar 0,03 lebih kecil dari $\alpha(0,05)$.

- Leverage memiliki pengaruh signifikan atas perubahan keputusan penggunaan derivative, karena nilai Sig.-nya sebesar 0,04 adalah lebih kecil dari $\alpha(0,05)$.

- Likuiditas tidak berpengaruh signifikan atas perubahan keputusan penggunaan derivative, karena nilai Sig.-nya sebesar 0,97 adalah lebih besar dari $\alpha$ pada level manapun $(0,01 ; 0,05 ; 0,10)$.

- Ukuran dewan tidak berpengaruh signifikan terhadap perubahan keputusan penggunaan derivative, karena nilai Sig.nya sebesar 0,68 adalah lebih besar dari $\alpha$ pada level manapun $(0,01 ; 0,05 ; 0,10)$.

- Komisaris Independen tidak berpengaruh signifikan terhadap perubahan keputusan penggunaan derivative, karena nilai Sig.nya sebesar 0,15 adalah lebih besar dari $\alpha$ pada level manapun $(0,01 ; 0,05 ; 0,10)$

- Komite Audit memiliki pengaruh yang signifikan terhadap perubahan keputusan penggunaan derivative, karena nilai Sig.nya sebesar 0,08 adalah lebih kecil dari $\alpha$ $(0,10)$.

Bukti empiris menunjukkan sebagian besar perusahaan di sektor logam dan sejenisnya di BEI dari tahun 2012 sampai 2014 tidak menggunakan derivatif sebagai lindung nilai dan hanya bergantung pada lindung nilai alami. Pada laporan tahunan dan keuangan disebutkan mereka terkena risiko keuangan, terutama berasal dari devisa namun banyak dari mereka lebih memilih mengelola risiko secara alami. Fluktuasi devisa akan menyesuaikan risikonya sendiri. Solusi lain yang mereka gunakan untuk mengelola risiko adalah melakukan transaksi spot. 
Tabel 7. Parameter Estimasi

\begin{tabular}{|c|c|c|c|c|c|c|c|}
\hline & \multirow[b]{2}{*}{ Estimate } & \multirow[b]{2}{*}{ Std. Error } & \multirow[b]{2}{*}{ Wald } & \multirow[b]{2}{*}{$\mathrm{df}$} & \multirow[b]{2}{*}{ Sig. } & \multirow{2}{*}{$\begin{array}{c}\text { Likelihood } \\
\exp (b)\end{array}$} \\
\hline & & & & & & & \\
\hline \multirow[t]{3}{*}{ Threshold } & {$[$ Derivative $=0]$} & 49.034 & 23.052 & 4.524 & 1 & .033 & $1.97 \mathrm{E}+21$ \\
\hline & {$[$ Derivative $=1]$} & 51.558 & 23.635 & 4.758 & 1 & .029 & $2.46 \mathrm{E}+22$ \\
\hline & {$[$ Derivative $=2]$} & 73.785 & 36.900 & 3.998 & 1 & .046 & $1.11 E+32$ \\
\hline \multirow[t]{6}{*}{ Location } & Firm_size & .003 & .001 & 4.736 & 1 & .030 & 1.00 \\
\hline & Leverage & 1.275 & .617 & 4.271 & 1 & .039 & 3.58 \\
\hline & Liquidity & -.003 & .078 & .002 & 1 & .965 & 1.00 \\
\hline & BS & -.355 & .846 & .176 & 1 & .675 & 0.70 \\
\hline & IBC & 16.522 & 11.345 & 2.121 & 1 & .145 & $1.50 \mathrm{E}+07$ \\
\hline & $\mathrm{AC}$ & 11.720 & 6.730 & 3.033 & 1 & .082 & $1.23 \mathrm{E}+05$ \\
\hline
\end{tabular}

Sumber: Diolah Peneliti, Tahun 2015.

Hanya ada tiga jenis derivatif yang digunakan di industri ini, yaitu kontrak opsi, forward, dan swap hanya dengan jumlah total yang digunakan setiap tahun sebagai berikut:

- Pada tahun 2012, ada 2 kontrak opsi, 3 kontrak forward, dan 2 kontrak swap;

- Pada tahun 2013, ada 3 kontrak opsi, 4 kontrak forward, dan 1 kontrak swap;

- Pada 2014, ada 3 kontrak opsi, 3 kontrak forward, dan 1 kontrak swap; dan

- Dalam tiga tahun, ada 8 kontrak opsi, 10 kontrak forward, dan 4 kontrak swap.

\section{Pengaruh Ukuran Perusahaan terhadap Penggunaan Derivatif}

Analisis data menunjukkan bahwa ukuran perusahaan memiliki dampak positif yang signifikan terhadap penggunaan derivatif sebagai keputusan lindung nilai. Hal ini dapat dilihat dari pengujian hipotesis dimana nilai signifikansi ukuran perusahaan adalah 0,03 yang kurang dari 0,05 pada tingkat signifikansi 5\%. Keputusan lindung nilai untuk menggunakan derivatif akan meningkat 3,58 kali bila terjadi perubahan dalam ukuran perusahaan sebesar Rp. 1,-. Hasil ini konsisten dengan penelitian Prevost et al. (2000) serta Berkman dan Bradbury (1996) yang membandingkan perusahaan kecil dan besar dalam menggunakan derivatif sebagai keputusan lindung nilai. Derivatif lebih mungkin digunakan pada perusahaan besar dan juga penelitian Nance et al. (1993),
Nguyen dan Faff $(2002,2003)$, serta Lantara (2012).

Hasil penelitian ini juga mengatakan bahwa perusahaan dengan ukuran perusahaan terbesar di antara yang lain adalah satusatunya perusahaan yang menggunakan tiga jenis derivative, yaitu opsi, forward, dan swap selama tiga tahun. Hal ini disebabkan oleh besarnya risiko yang dihadapi oleh perusahaan ukuran besar. Semakin besar ukuran perusahaan, semakin besar risikonya. Karenanya, mereka cenderung menggunakan derivatif sebagai alat lindung nilai untuk melindungi aset mereka. Apalagi perusahaan besar cenderung menghadapi pasar global yang membuat mereka lebih terpapar terhadap pertukaran mata uang asing daripada perusahaan kecil. Kegiatan ini memerlukan alat manajemen untuk melakukan lindung nilai terhadap eksposur valuta asing sehingga derivatif muncul sebagai solusi untuk masalah ini.

\section{Pengaruh Leverage terhadap Penggunaan Derivatif}

Dalam penelitian ini, leverage dihitung dengan DER, yaitu rasio hutang terhadap ekuitas. Analisis data menunjukkan bahwa leverage memiliki dampak positif yang signifikan terhadap penggunaan derivatif sebagai keputusan lindung nilai. Hal ini dapat dilihat dari pengujian hipotesis dimana nilai signifikansi leverage adalah 0,04 yang kurang dari 0,05 pada tingkat signifikansi $5 \%$. 
Hasilnya, hipotesis yang diajukan diterima. Bila ada perubahan leverage $1 \%$, tingkat kemungkinan perusahaan untuk menggunakan derivatif adalah 1. Hasil ini mendukung penelitian Warner (1977), Geczy et al. (1997), Guay dan Kothari (2003), serta Nguyen dan Faff (2003), yang menyimpulkan bahwa semakin banyak hutang yang dimiliki perusahaan, semakin banyak derivatif yang digunakan sebagai lindung nilai terhadap biaya kebangkrutan. Namun, hasil ini tidak terkait dengan penelitian Triki (2005) yang menyatakan leverage memiliki dampak negatif terhadap penggunaan derivatif.

Pelanggan di suatu perusahaan memiliki biaya tertentu pada tingkat tertentu, semakin banyak hutang dalam struktur modal, semakin besar biaya. dari hutang akan timbul. Seiring bertambahnya biaya, kenaikan risiko akan menyusul. Dengan demikian, perusahaan memerlukan alat untuk meminimalkan risiko keuangan ini dengan menggunakan derivatif.

\section{Pengaruh Likuiditas terhadap Penggunaan Derivatif}

Menurut analisis data, likuiditas tidak berpengaruh signifikan terhadap penggunaan derivatif sebagai keputusan lindung nilai. Hal ini dapat dilihat dari pengujian hipotesis dimana nilai signifikansi likuiditas adalah 0,97 yang lebih besar dari 0,01 pada tingkat signifikan $1 \%$, lebih besar dari 0,05 pada tingkat signifikan $5 \%$, dan lebih tinggi dari 0,10 pada tingkat signifikansi $10 \%$. Akibatnya, hipotesis yang diajukan ditolak. Hasil ini tidak sesuai dengan penelitian Carter dan Sinkey (1998), Berkman dan Bradbury (1993), serta Nguyen dan Faff (2002), yang menyatakan bahwa derivatif diperlukan bila sebuah perusahaan dalam masalah likuiditas. Banyak laporan tahunan perusahaan yang menjadi objek penelitian menyatakan bahwa aktivitas lindung nilai dikelola secara alami tanpa derivatif apapun.

\section{Pengaruh Tata Kelola Perusahaan yang Baik atas Penggunaan Derivatif}

Hanya komite audit yang memiliki dampak signifikan terhadap penggunaan derivatif di antara tiga variabel tata kelola perusahaan yang baik yang termasuk dalam penelitian ini. Menurut analisis data, board size tidak berpengaruh signifikan terhadap penggunaan derivatif sebagai keputusan lindung nilai. Hal ini dapat dilihat dari pengujian hipotesis dimana nilai signifikansi board size adalah 0,68 yang lebih besar dari 0,01 pada tingkat signifikan $1 \%$, lebih besar dari 0,05 pada tingkat signifikan $5 \%$, dan lebih tinggi dari 0,10 pada tingkat signifikansi $10 \%$. Akibatnya, hipotesis yang diajukan ditolak. Hasil ini tidak sesuai dengan studi Ferris et al. (2007) yang menyatakan bahwa semakin besar board size, semakin tinggi representasi dalam dewan direksi terkait memperbaiki kemungkinan aktivitas lindung nilai.

Dewan komisaris independen tidak berpengaruh signifikan terhadap penggunaan derivatif sebagai keputusan lindung nilai. Hal ini dapat dilihat dari pengujian hipotesis dimana nilai signifikansi dewan komisaris independen adalah 0,15 yang lebih besar dari 0,01 pada tingkat signifikan $1 \%$, lebih besar dari 0,05 pada tingkat signifikan $5 \%$, dan lebih dari 0,10 pada tingkat signifikansi $10 \%$. Akibatnya, hipotesis yang diajukan ditolak. Hasil ini tidak sesuai dengan penelitian Borokhovich et al. (2004) yang merangkum bahwa semakin besar kepemilikan manajerial independen, semakin besar motivasi sebuah perusahaan untuk menggunakan derivatif.

Analisis data juga menunjukkan bahwa komite audit memiliki dampak positif yang signifikan terhadap penggunaan derivatif sebagai keputusan lindung nilai. Hal ini dapat dilihat dari pengujian hipotesis dimana nilai signifikansi leverage adalah 0,08 yang kurang dari 0,10 pada tingkat signifikansi $10 \%$. Akibatnya, hipotesis yang diajukan diterima. Ketika perusahaan sampel memiliki satu orang tambahan yang duduk di komite audit, probabilitas keputusan lindung nilai dengan menggunakan derivatif akan meningkat 123.014,53 kali. Hasil ini mendukung penelitian Osuoha et al. (2015) yang menyatakan bahwa pengawasan dari komite audit mendorong penggunaan derivatif. Ketika perusahaan menghadapi risiko keuangan, komite audit akan mengusulkan 
sebuah solusi untuk menghindari kerugian. Dalam hal ini, aktivitas lindung nilai dengan menggunakan derivatif merupakan salah satu solusi yang ditawarkan.

Investasi sebagai alat lindung nilai sudah banyak diketahui dan digunakan oleh banyak perusahaan internasional di pasar global. Namun, perusahaan di Indonesia khususnya perusahaan logam dan sejenisnya pada 2012 hingga 2014 tidak menggunakan derivatif. Mereka cenderung melakukan lindung nilai atas risiko finansial dengan natural hedging. Istilah natural hedging atau lindung nilai alami berarti bahwa risiko dicegah tanpa aktivitas tertentu yang diterapkan untuk mengelolanya. Misalnya, jika perusahaan melakukan transaksi dengan perusahaan asing, maka akan terkena eksposur valuta asing., yaitu selisih antara mata uang lokal dan mata uang asing yang disebabkan oleh transaksi tersebut akan dipulihkan oleh pergerakan nilai tukar yang selalu berubah di sepanjang tahun. Cara lain yang digunakan oleh perusahaan untuk mengelola risiko keuangan yang ditemukan dalam penelitian ini adalah transaksi spot dan bukan menggunakan instrumen derivatif.

\section{KESIMPULAN}

Berdasarkan hasil pengujian hipotesis dengan model regresi logistik ordinal menggunakan SPSS versi 19 for Windows, maka dapat ditarik beberapa kesimpulan.

Pertama, ukuran perusahaan memiliki pengaruh yang signifikan terhadap keputusan lindung nilai industri logam dan sejenisnya, semakin besar total aset suatu perusahaan, semakin perusahaan akan menggunakan derivatif sebagai alat lindung nilai untuk melindungi aset perusahaan dan kegiatan operasional melawan risiko.

Kedua, leverage berpengaruh positif signifikan terhadap penggunaan derivatif sebagai keputusan lindung nilai pada perusahaan sektor logam dan sejenisnya di Indonesia. Semakin tinggi tingkat rasio hutang, semakin besar keputusan lindung nilai dilakukan untuk mengurangi dampak buruk dari risiko hutang.
Ketiga, likuiditas tidak memiliki dampak signifikan terhadap penggunaan derivatif sebagai keputusan lindung nilai pada perusahaan sekuritas dan produk logam yang terdaftar di Bursa Efek Indonesia (BEI).

Keempat, hanya komite audit yang memiliki pengaruh signifikan positif terhadap penggunaan derivative pada perusahaan logam dan sejenisnya di antara variabel lain yang diteliti sebagai unsur tata kelola perusahaan yang baik.

Kelima, dari enam variabel independen, pengaruh yang paling dominan terhadap kemungkinan penggunaan instrumen derivatif sebagai keputusan lindung nilai adalah variabel ukuran perusahaan. Semakin banyak aset yang dimiliki oleh perusahaan, semakin besar keinginan perusahaan untuk melindungi aset dari risiko yang mungkin terjadi. Risiko tersebut dilindung nilai dengan penggunaan instrumen derivatif. Oleh karena itu, ukuran perusahaan variabel memiliki pengaruh paling dominan terhadap penggunaan instrumen derivatif sebagai pengambilan keputusan lindung nilai.

\section{Saran}

Perusahaan yang akan menggunakan derivatif sebagai instrumen lindung nilai diharapkan dapat memperhatikan informasi internal perusahaan terutama ukuran perusahaan, leverage, dan komite audit. Hal ini karena temuan penelitian ini adalah ukuran perusahaan memiliki pengaruh terbesar terhadap faktor penentu penggunaan derivatif, diikuti oleh leverage dan komite audit. Selain itu, seiring dengan meningkatnya aset, perusahaan perlu melindungi asetnya sendiri dari risiko, dan juga perlu mencegah biaya hutang yang mungkin terjadi saat hutang naik.

Komite Audit harus memberikan saran tentang penggunaan derivatif untuk melakukan lindung nilai risiko, terutama dari selisih kurs dan suku bunga. Perusahaan di Indonesia, terutama tipe perusahaan yang melakukan banyak aktivitas transaksi dengan perusahaan asing, maka disarankan untuk mempertimbangkan derivatif sebagai alat mereka dalam mengelola eksposur valuta asing. 
Lebih lanjut, seorang investor yang akan berinvestasi di industri logam dan sejenisnya yang terdaftar di BEI harus memperhatikan ukuran perusahaan, leverage, dan komite auditnya. Selanjutnya, risiko perusahaan dan bagaimana mengelola risiko harus dipertimbangkan juga; apakah derivatif digunakan atau tidak.

Untuk tujuan akademik, penelitian ini diharapkan dapat memberikan pengetahuan tambahan dan dapat berkontribusi dalam penelitian lain mengenai penggunaan instrumen derivatif sebagai aktivitas lindung nilai. Untuk penelitian lebih lanjut, disarankan untuk memasukkan faktor eksternal seperti suku bunga, fluktuasi mata uang, dan pajak, serta faktor internal lainnya yang dikecualikan dalam penelitian ini, seperti peluang pertumbuhan dan tahun pendirian perusahaan untuk memberikan yang lebih baik. wawasan tentang faktor penentu penggunaan derivatif.

Berdasarkan tujuan dan sasaran penelitian, ada enam hipotesis yang dibuat dalam penelitian ini. Hipotesis dibuat berdasarkan enam variabel independen yang diteliti dalam penelitian ini, yaitu ukuran perusahaan, leverage, likuiditas, board size, dewan komisaris independen, dan komite audit. Selain itu, ada aspek internal lainnya yang mungkin menjadi alasan penggunaan derivative, selain dari variabel prediktor termasuk dalam penelitian ini. Selain itu, perusahaan yang menjadi objek penelitian ini juga terbatas pada perusahaan logam dan sejenisnya yang terdaftar di BEI dari tahun 2012 sampai 2014 dengan beberapa kriteria tertentu. Akibatnya, hanya enam hipotesis yang dianalisis dalam penelitian ini dengan hanya 39 sampel; yang juga bisa dikatakan sebagai keterbatasan penelitian ini.

\section{DAFTAR PUSTAKA}

Ameer, R. 2010. Determinant of Corporate Hedging Practices in Malaysia. International Business Research. Vol. 3, No. 2, hal. 120-130.

Ang, R. 1997. Buku Pintar Pasar Modal Indonesia. Jakarta: Mediasoft Indonesia.
Beasley, M., Carcello, J., Hermanson, D. dan Lapides, P. 2000. Fraudulent Financial Reporting: Consideration of Industry Traits and Corporate Governance Mechanisms. Accounting Horizons. Vol. 14, No. 4, hal. 441-454.

Bellalah, M. 2010. Derivatives, Risk Management \& Value. Singapore: World Scientific.

Berkman, H. dan Bradbury, M. 1996. Empirical Evidence on The Corporate Use of Derivatives. Financial Management. Vol. 25, No. 2, hal. 513.

Bloomberg. 2015. Retrieved from USD IDR Spot Exchange Rate: http://www. bloomberg.com/quote/USDIDR:CUR. Diunduh tanggal 20 September.

Borokhovich, K., Brunarski, K., Crutchley, C. dan Simkins, B. 2004. Board Composition and Corporate Use of Interest Rate Derivatives. The Journal of Financial Research. Vol. 27, No. 2, hal. 199-216.

Carter, D. dan Sinkey, J. 1998. The Use of Interest Rate Derivatives by EndUsers: The Case of Large Community Banks. Journal of Financial Services Research. Vol. 14, hal. 17-34.

Cavana, R., Delahaye, B. dan Sekaran, U. 2001. Applied Business Research: Qualitative and Quantitative Methods. Queensland: John Wiley \& Sons Australia.

Collis, J. dan Hussey, R. 2009. Business Research: A Practical Guide for Undergraduate and Postgraduate Students. London: Palgrave Macmillan.

Crouhy, M., Galai, D. dan Mark, R. 2006. The Essentials of Risk Management. New York: McGraw-Hill.

Dionne, G. dan Triki, T. 2013. On Risk Management Determinants: What Really Matter? European Journal of Finance. Vol. 19, No. 2, hal. 145-164.

Dionne, G. dan Triki, T. 2005. Risk Management and Corporate Governance: The Importance of Independence and Finacial Knowledge 
for The Board and The Audit Committee. HEC Montreal Working Paper No. 05-03. May. http://dx.doi.org/10.2139/ssrn.730743, Diunduh tanggal 20 September 2015.

Eales, B. 1994. Financial Risk Management. England: McGraw-Hill.

Ferris, S., Jandik, T., Lawless, R. dan Makhija, A. 2007. Derivative Lawsuits as a Corporate Governance Mechanism: Empirical Evidence on
Board Changes Surrounding Filings. Journal of Financial and Quantitative Analysis. Vol. 42, No. 1, hal. 143-165.

Froot, K., Scharfstein, D. dan Stein, J. 1993. Risk Management: Coordinating Corporate Investmment and Financing Policies. Journal of Finance. Vol. 48, No. 5, hal. 1629-1658. 